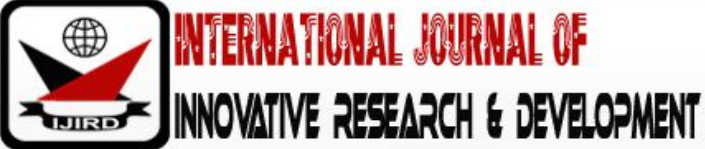

ISSN 2278 - 0211 (Online)

\section{Occupational and Ecotoxicological Hazards Associated with Ishiagu Quarry Industry in South-Eastern Nigeria}

\author{
Obinwanne Carol Chioma \\ Medical Practitioner, Department of Medical and Health Services, \\ Federal Polytechnic Nekede Owerri, Nigeria \\ Ozoh P.T.E \\ Professor, Department of Biotechnology, Federal University of Technology Owerri, Nigeria \\ Opara F. N, \\ Professor, Department of Biology Federal University of Technology Owerri, Nigeria \\ Okereke J.N. \\ Senior Lecturer, Department of Biotechnology Federal University of Technology Owerri, Nigeria \\ Udebuani Angela Chika \\ Department of Biotechnology Federal University of Technology Owerri, Nigeria
}

\begin{abstract}
:
The health status of workers and air quality of work environment were assessed and analyzed in the Ishiagu Quarry industry, South-Eastern Nigeria. Blood and sputum samples collected were analyzed using standard laboratory procedures, chest radiography and hair washings from workers were carried out following standard protocols. Air quality was determined using CROWCON Gasman II monitor/analyzer. Average haemoglobin of workers in Ishiagu quarry industry was $70.43 \pm 6.16 \%$. Average values of white blood cell (total count) were: $5198.15 \pm 341.69 \mathrm{mcl}$. Average values of eosinophil (direct count) were $5.60 \pm 1.84 \%$ and within the standard limit. Average values of Erythrocyte Sedimentation Rate recorded was $54.7 \pm 25.61 \mathrm{~mm} / \mathrm{hr}$. Chest radiology revealed that $130(13 \%)$ Ishiagu quarry workers had consolidation of the lung. Heavy metal level from hair washings among Ishiagu quarry workers was Lead $0.26 \pm 0.03 \mathrm{mg} / \mathrm{l}$; Cadmium, $0.12 \pm 0.01 \mathrm{mg} / \mathrm{l}$; Chromium. $0.11 \pm 0.06 \mathrm{mg} / \mathrm{l}$; Arsenic, $0.02 \pm 0.01 \mathrm{mg} / \mathrm{l}$ and Mercury, $0.01 \pm 0.10 \mathrm{mg} / \mathrm{l}$. Average values of air quality were $\mathrm{NO}_{2}$, $0.65 \pm 0.32 \mathrm{ppm} ; \mathrm{CO}, 13.83 \pm 1.61 \mathrm{ppm} ; \mathrm{CO}_{2}, 17 \pm 3.05 \% ; \mathrm{SO}_{2}, 1.15 \pm 0.38 \mathrm{ppm}$. The concentration of Volatile Organic Compound was $0.40 \pm 0.20 \mathrm{ppm}$. Particulate matter at Ishiagu quarry industry had raised level of $59.7 \pm 22.53 \mu \mathrm{g} / \mathrm{m}^{3}$. Common diseases observed were pulmonary consolidation (biomarker to lung cancer)/ pneumonitis.
\end{abstract}

Keywords: Occupational hazards, ecotoxicology, health status, air quality

\section{Introduction}

The escalation of industries in Ishiagu, South-Eastern Nigeria has resulted to various occupational and ecotoxicological hazards which include threats to biodiversity (Achyut, Shrestha, Shree-Sen, Uprteti, \& Gautam, 2009) health hazards and archaeological properties (Aroh, et al. 2010). The ecosystem was previously well-endowed and has arable terrain that can sustain a wide variety of crops, economic trees, and various species of freshwater fish than any other ecosystem in South-Eastern, Nigeria. Pollutants generated by various industries and factories are often considered to be one of the prime factors contributing to air, water and soil pollutions. The water is contaminated with dangerous chemicals, (Garcia, 2017) radioactive materials and heavy metals (Hall, 2017) or organic sludge which negatively impacts on marine life, humans, and the environments. It is estimated that about $50 \%$ of all pollution is as a result of industrial and manufacturing activities, resulting to serious consequences ( $\mathrm{Liu}, 2017)$ which include global warming from steady rise of industrial activities and release of greenhouse gases including carbon (iv) oxide $\left(\mathrm{CO}_{2}\right)(\mathrm{Gant}, 2017)$ and methane $\left(\mathrm{CH}_{4}\right)$ into the atmosphere. 


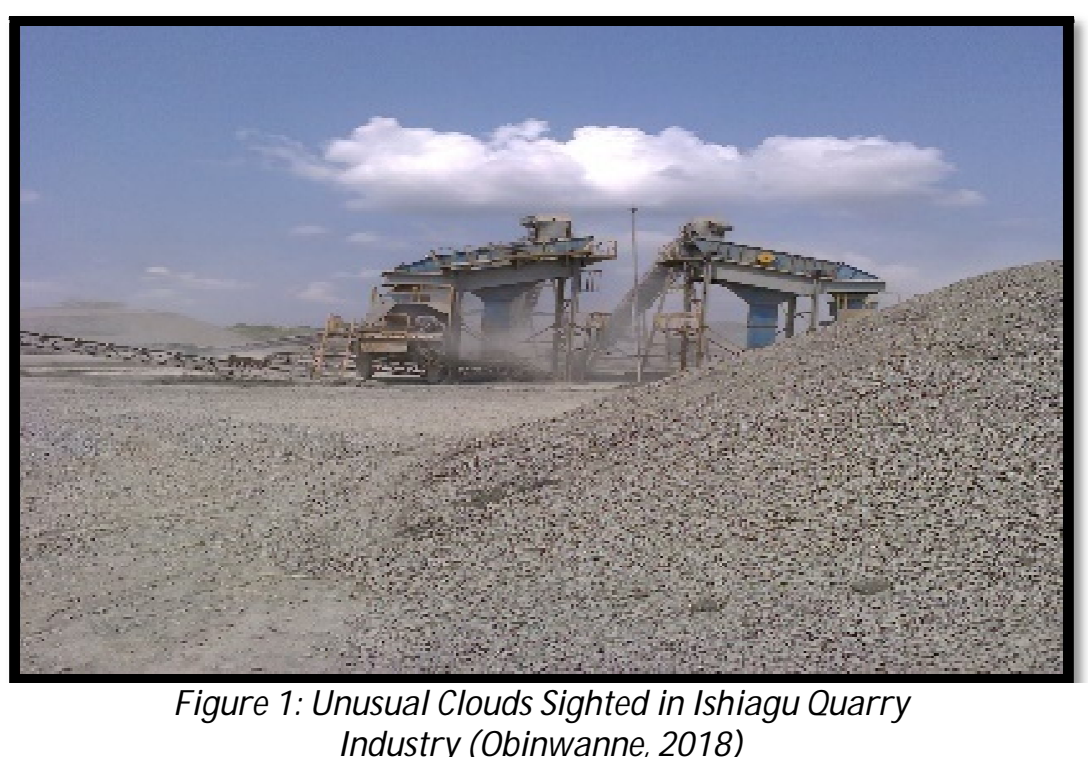

Increase in atmospheric concentration of these gases leads to the formation of acid rains and heightened incidences of respiratory disorders among humans (Crook, 2017). Globally, pollution is the commonest cause of disease and premature death. An estimated 9 million premature deaths occurred in 2015; 16\% of all deaths worldwide (Landrigan, 2018). The need to ascertain the health status of workers and the air quality of work environment through the assessment of hazards on both workers and the environment, hence, this study.

\section{Methodology}

\subsection{Area of study}

The quarry site under study is in Ishiagu town in Ivo Local Government Area, Ebonyi State, South-Eastern Nigeria. Ishiagu is located on the plains of flat grassland and the damaged pipeline and oil spill in the area has resulted in various environmental hazards (Aroh et al. 2010).

\subsection{Collection of Sample}

Samples of blood, sputum, and hair washings were collected from workers and workers examined for a chest xray. Air quality around the workplace and adjoining environment were sampled in Ishiagu quarry industry, in SouthEastern Nigeria. The ethical permit was obtained from the appropriate authority before samples were collected from workers.

\subsubsection{Preparation of Blood Samples}

Human subjects for this study consisted of twenty-three male and female industrial workers within the age group twenty-one to seventy years who volunteered to participate and had been in the job for up to three years. Blood sample (2ml) was collected for Full Blood Count (FBC) and Erythrocyte Sedimentation Rate.

\subsubsection{Preparation of Sputum Samples}

The quality and quantity of the early morning sputum samples were examined by looking at it through the clear sides of the container. Hands were washed with running water and soap after handling containers with sputum samples. All waste contaminated with sputum were discarded in 10\% sodium hypochlorite solution, incinerated and buried.

\subsubsection{Preparation of Chest Radiography (Lateral and Posterior-Anterior Views)}

Both male and non-pregnant female workers were prepared for the radiology examination. The loose gown that would not interfere with the x-ray images was put on. Jewellery, removable dental appliances, eyeglasses and any metal objects were removed.

\subsubsection{Preparation of hair sample for Lead accumulation}

Strands of hair of workers were washed with distilled water and solution assessed for lead using Atomic Absorption Spectrophotometer (AAS) at the appropriate wavelength.

\subsection{Air Quality}

Air quality around each workplace and the adjoining environment was sampled using CROWCON Gasman 11 monitor/ analyzer, a personal gas detector which can continuously monitor the level of oxygen or the presence of a single toxic or inflammable gas. 


\subsection{Laboratory Investigations for FBC}

The samples (from human and the environment) was subjected to laboratory investigations. To ascertain the health status of workers. Full blood count (FBC): packed cell volume (PCV), Haemoglobin (Hb), white blood cells (WBC) total and differential, and platelets, were determined using the QBC II plus centrifugal haematology system as described by Adams (1987). The QBC II plus centrifugal haematology screening system was for obtaining seven quantitative clinical values from blood in a centrifugal tube and performed in a temperature environment of $20^{\circ}$ to $32^{\circ} \mathrm{C}$. The dipotassium ethylenediaminetetraacetic acid ( $\mathrm{K}_{2} \mathrm{EDTA}$ ) anticoagulant (concentration of 1.5 - $2.2 \mathrm{mg} \mathrm{ml}^{-1}$ ) with venous blood specimen was gently mixed 5 to 10 times to allow a complete interaction between blood and anticoagulant. Blood was filled to the line (mark) and samples investigated within 6hours to achieve optimum conditions. The QBC system pipette was used to aspirate venous blood into the venous tube. The distal part of the tube was pressed into closure, tube removed from pipette and closure twisted to form a leak-tight seal. The tube was slide over float and gently pushed until float was inside the tube as far as the possible and sealed end of the tube was carefully lifted until float was free of tray slot. The tube was lowered into the rotor slot of QBC centrifuge and balanced, rotor cover installed, lid closed and then centrifuged for 5 minutes. The tube was transferred to QBC reader and 'VEN' mode key of the reader pressed (to read venous blood). By turning the transport knob to advance the tube in the reader, the tube was positioned so the tip of the cursor points directly to the colour interphase of interest (interphases 1-6). To enter/ record the value for the haematological parameter at the particular interphase, the ENTER button was pressed.

\subsection{Erythrocyte Sedimentation Rate}

Modified Westergren Method (National Committee for Clinical Standards, 1993). The ESR was set up within six hours after collection. The pipette was used to add $0.5 \mathrm{ml}$ of $0.85 \%$ saline in a labelled $13 \mathrm{x} 100 \mathrm{~mm}$ test tube. Then $2.0 \mathrm{ml}$ of wellmixed whole- blood in EDTA bottle was added and mixed to obtain an even suspension. A pipetting device was used to fill the Westergren pipette to the "0" mark $( \pm 1 \mathrm{~mm})$ with the diluted blood sample and placed in a vertical position in the pipette rack for an hour, exactly when the distance $(\mathrm{mm})$ between the meniscus of the plasma and the top of the erythrocytes is read as the ESR.

\subsection{Smear Staining by Hot Ziehl - Neelsen Method (Tankeshwar, 2013)}

From a sputum sample examined as (+), several smears were made and allowed to air dry (for positive control). From a known negative sample several slides were also prepared and allowed to air dry (for negative control). The numbered slides were placed with air-dried smears on a staining rack that was placed across in a sink in batches of not more than 12 (including controls). It was ensured that the slides did not touch each other and there was enough room to flame underneath the slides, a positive and negative control slides were included for every batch staining. The entire slides were flooded with strong carbol fuchsin and later was heated slowly until it was steaming and maintained for 3-5 minutes by using intermittent heat. A tap to which a hose was connected was used to rinse slides in a gentle stream of running water until all excess stain was washed off. The slides were flooded with a decolourising solution and left for 3 minutes and rinsed thoroughly with water and excess drained. The slides were flooded with counterstain (methylene blue) and left for not more than 3 minutes and rinsed thoroughly with water, excess drained and allowed to air dry. The stained slides were examined with the aid of X100 microscope.

\subsection{Chest X-ray}

In chest radiography two views were the posterior-anterior and lateral views. The client's hands were positioned on the hips and chest pressed against the image recording plate. For the second view, the client's side was against the image plate with arms elevated and asked to hold the breath for few seconds while the x-ray picture was taken to reduce the possibility of a blurred image. The radiographer activated the x-ray machine from the next room. The entire chest x-ray examination, from positioning to obtaining and verifying the images, was completed within 15 minutes.

\subsection{Lead accumulation on hair Strands}

Hair of workers was washed with distilled water and solution assessed for lead using Atomic Absorption Spectrophotometer (AAS) at the appropriate wavelength.

\subsection{Air quality (CROWCON Gasman 11Method):}

Air Quality (AQ) was determined with CROWCON Gasman 11 which calculated electronically AQ emissions for four (4) different air quality pollutants namely: Particulate matters (PM), Sulphur (iv) Oxide $\left(\mathrm{SO}_{2}\right.$ ), Nitrogen oxides (NOx) and non-methane volatile organic compounds (NMVOCs). $\mathrm{CO}_{2}$ was determined with CROWCON (2014) analyzers.

\section{Results}

\subsection{Demographic Data of Workers in Ishiagu Quarry Industry}

A total of 23 workers, participated in the assessment of the health status of workers in and around Ishiagu quarry industry, South-Eastern Nigeria. Age and Gender Distribution of Workers from Ishiagu Quarry Industry that participated in Assessment of Health Status is shown in Table 1. Ishiagu quarry industry had 23 volunteers, out of which 12 were female while 11 were male; all in the age group of 21-70 years. Of Workers from Ishiagu Quarry Industry (Obinwanne, 2018) 


\begin{tabular}{|c|c|c|}
\hline Age(years) & Gender & No. \\
\hline $21-30$ & Male & 1 \\
& Female & 4 \\
$31-40$ & Male & 4 \\
& Female & 4 \\
$41-50$ & Male & 3 \\
& Female & 3 \\
$51-60$ & Male & 1 \\
& Female & 1 \\
$61-70$ & Male & 2 \\
& Female & 0 \\
& Total & 23 \\
\hline
\end{tabular}

Table 1: Age and Gender Distribution of Workers from Ishiagu Quarry Industry (Obinwanne, 2018)

\subsubsection{Health Status of Workers in the Ishiagu Quarry Industry}

Table 2 shows the health status of workers in the Ishiagu industry. The average of various parameters investigated was compared. The Chest X-ray showed the average number of workers 130 (13\%) had consolidation of the lung. Sputum result for Acid fast bacilli was negative. For Full blood count, the average haemoglobin of $70.43 \pm 6.16 \%$ was observed. Total white blood cell count of $5198.15 \pm 341.69 \%$ was observed. Direct count was: Neutrophils $(49.01 \pm 2.20 \%)$; Lymphocytes level of $42.59 \pm 0.82 \%$; Monocytes (2.62 $\pm 0.40 \%)$; Basophils level was $0 \pm 00 \%$, Eosinophil (5.6 $\pm 1.84 \%)$; Erythrocyte sedimentation rate was $54.7 \pm 25.61 \%$ and exceeded the normal limit.

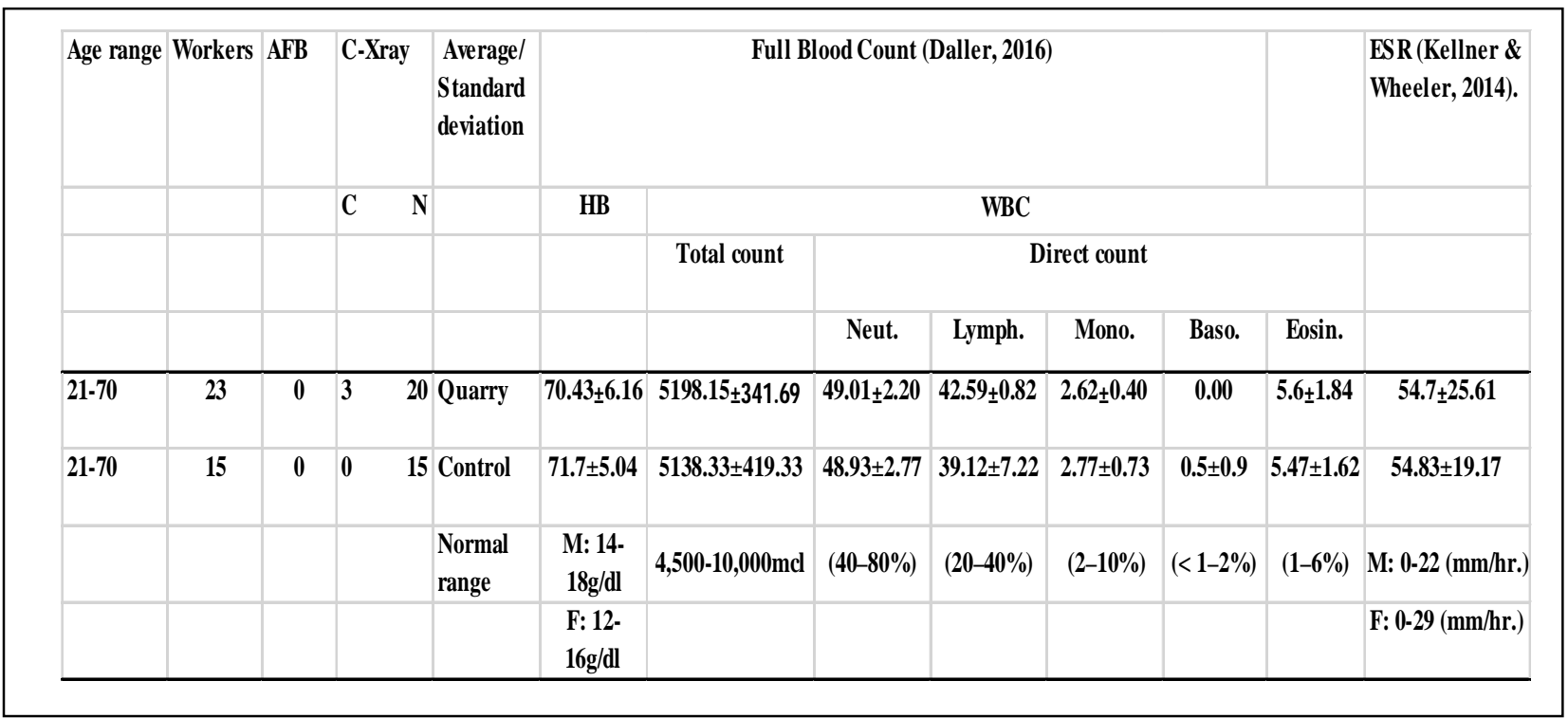

Table 2: Health Status of Workers in Ishiagu Quarry Industry, South-Eastern Nigeria (Obinwanne, 2018)

\subsubsection{Heavy Metal Level on the Hair of Workers}

As shown in Table3, the level of some heavy metals on the hair of workers in Ishiagu quarry industry. Lead $0.26 \pm 0.03 \mathrm{mg} / \mathrm{l}$; Cadmium, $0.12 \pm 0.01 \mathrm{mg} / \mathrm{l}$; Chromium, $0.11 \pm 0.06 \mathrm{mg} / \mathrm{l} ;$ Arsenic, $0.02 \pm 0.01 \mathrm{mg} / \mathrm{l}$ and Mercury, $0.01 \pm 0.10 \mathrm{mg} / \mathrm{l}$. The level of arsenic was below the upper limit of the normal value of the FEPA standard for industries.

\begin{tabular}{|c|c|c|c|}
\hline Parameters & \multicolumn{2}{|c|}{ Quarry } & FMEnv Standard (1991) \\
\hline & Average & Control & 0.05 \\
\hline Lead (mg/l) & $0.26 \pm 0.03$ & $0.17 \pm 0.01$ & 0.01 \\
\hline Cadmium (mg/l) & $0.12 \pm 0.01$ & $0.05 \pm 0.01$ & 0.10 \\
\hline Chromiuim (mg/l) & $0.11 \pm 0.06$ & 0.00 & 0.20 \\
\hline Arsenic $(\mathrm{mg} / \mathrm{l})$ & $0.02 \pm 0.01$ & $0.01 \pm 0.01$ & 0.00 \\
\hline Mercury $(\mathrm{mg} / \mathrm{l})$ & $0.01 \pm 0.10$ & $0.10 \pm 0.08$ & \\
\hline
\end{tabular}

Table 3: Heavy Metal on Human Hair in Ishiagu Quarry Industry (Obinwanne, 2018) 


\subsection{Air quality in Ishiagu quarry industry, South-Eastern Nigeria}

The result of air quality is shown in Table 4 . The value of $\mathrm{NO}_{2}$ was $0.65 \pm 0.32 \mathrm{ppm}$. $\mathrm{CO}, 13.83 \pm 1.61 \mathrm{ppm}$; carbon (iv) oxide $\left(\mathrm{CO}_{2}\right) 17 \pm 3.05 \mathrm{ppm} ; \mathrm{SO}_{2}, 1.15 \pm 0.38$. The concentration of $\mathrm{VOC}$ was $0.40 \pm 0.20 \mathrm{ppm}$ and $\mathrm{TSPM}_{10}$ was $59.7 \pm 22.53 \mu \mathrm{g} / \mathrm{m}^{3}$. Air quality with respect to the gases analyzed in this study showed that the Ishiagu quarry industry had average values well above the FEPA (1991) standard hence, had poor air quality.

\begin{tabular}{|c|c|c|c|}
\hline & \multicolumn{2}{|c|}{ Quarry } & \multirow{2}{*}{ FEPA (1991) } \\
\hline Parameters & Average & Control & $0.04-0.06$ \\
\hline $\mathrm{NO}_{2}, \mathrm{ppm}$ & $0.65 \pm 0.32$ & 0.00 & 10.00 \\
\hline $\mathrm{CO}, \mathrm{ppm}$ & $13.83 \pm 1.61$ & $12.20 \pm 0.08$ & $\mathrm{NS}$ \\
\hline $\mathrm{CO}_{2}(\%)$ & $17 \pm 3.05$ & $6.00 \pm 1.63$ & 0.01 \\
\hline $\mathrm{SO}_{2}, \mathrm{ppm}$ & $1.15 \pm 0.38$ & $0.30 \pm 0.16$ & $\mathrm{NS}$ \\
\hline $\mathrm{VOCs}, \mathrm{ppm}$ & $0.40 \pm 0.20$ & $0.20 \pm 0.08$ & 0.25 \\
\hline $\mathrm{TSPM} 10 \mathrm{~g} / \mathrm{m}^{3}$ & $59.7 \pm 22.53$ & $40.60 \pm 0.08$ & \\
\hline
\end{tabular}

Table 4: Air Quality in Selected Industries (Obinwanne, 2018)

\subsection{Statistical Analysis}

Analysis of Variance (ANOVA) was used to determine equality between the population mean and that difference between samples was by chance.

Null hypothesis 1: There is no significant ecotoxicological and occupational hazards associated with the Ishiagu quarry industry. ANOVA Single Factor was used which determined that F value was 29.2601381 > F critical value of 4.493998478, thus Null hypothesis 1 was rejected.

Null hypothesis 2: There is no significant health effect of ecotoxicological and occupational hazards on workers. ANOVA Single Factor was used which determined that F value was 2026.176634 > F critical value of 4.493998478 and Null hypothesis 2 , rejected.

Null hypothesis 3: There is no significant effect of ecotoxicological and occupational hazards on air quality around the work area. ANOVA single factor was used which determined the difference between samples of air quality and health status, F value was $21.51838696>$ F critical value 2.533554548. The null hypothesis was rejected.

\section{Discussion}

\subsection{Demographic Data of Workers in Ishiagu Quarry Industry}

The occupation of an individual is part of his everyday life, and the nature of the occupation will definitely affect the individual's health status. The strategy for age and gender distribution of assessment of health status at the workplace was important and aimed at achieving a sustained reduction of occupational hazards and diseases in South Eastern Nigeria. Increasing the healthy life-span spent in work could contribute to addressing the age-related expenditure problem as average experience and productivity level could rise and longer working lives could compensate for age-related increases in, health care utilization. Gender interacts with the social, economic and biological determinants and consequences of diseases to create different health outcomes for males and females. Its roles and characteristics do not exist in isolation but are defined in relation to one another. The different roles of male and female workers in the industry affect risks of infection. Exposure of male and female workers to diseases in certain work environments are more pronounced in certain age group and sex. Females may suffer more ill-health because they are employed in monotonous and repetitive work and are likely to develop repetitive strain injuries (Ostlin, 2000) or to be exposed to carcinogenic substances. Often, males are involved in dynamic and physically challenging jobs, such as quarrying, with considerable lifting and moving of heavy loads which expose them to work-related accidents resulting in death.

\subsubsection{Health Status of Workers in Ishiagu Quarry Industry}

The consolidation of the lung occurred in various degrees among the Ishiagu quarry industrial workers and could be associated with volume loss of about 25\% (David, 2007). The predisposing factors of pulmonary consolidation can also cause some degree of collapse. Early in the course of lung injury, heterogeneous changes in lung morphology may give rise to lung zones that consist of normal lung regions; potentially infectious lung regions within the mid portion of the lungs; gravity-dependent lung; areas of markedly inflated lung tissue and consolidation. (James, Haenel, Jeffrey, Johnson, 2011). Chronic pulmonary consolidations have eosinophilic pneumonia as a differential diagnosis (Richard \& Kradin, 2017). Clients present with a cough, breathlessness, chronic pulmonary consolidations that may wax and wane. Asthma may also be a feature (Richard \& Kradin, 2017).

The average haemoglobin of the workers was $70.43 \pm 6.16 \%$ measured from venous samples. Some studies suggest that haemoglobin values measured in capillary samples are higher than those measured in venous samples, potentially leading to false-negative results (WHO, UNICEF, UNU, 2001). The amount of iron in the blood can be estimated with haemoglobin concentration (WHO, 2007). The level of white blood cells was $5198.15 \pm 322.1450525$ which is within normal limits. In the study carried out by Luo, Hsieh, Chang \& Hsu (2002) there was a significantly lower mean white blood cell count in male workers of photolithography, in Taiwan. White blood cells originate in the bone marrow but circulate throughout the bloodstream and are an important part of the immune system. There are white blood cells 
differentials: neutrophils, lymphocytes, eosinophil, monocytes, and basophils. A low or high white blood cells count may have an underlying blood disorder or other medical condition. A low count referred to as leucopenia can be triggered by severe infections, autoimmune disorders, bone marrow damage, some medications, such as antibiotics. This study suggests that leukopenia is a potential health effect of industrial hazards. The differential count was normal except the eosinophil that was raised in different age groups and in both male and female workers, even in the control samples. This is an inflammatory marker that has been implicated in coronary heart disease. In the study carried out by AbdElhamid, et al. (2017) on 'Assessment of Allergy Marker Leucocyte (Eosinophil) Count and other Blood Cells Parameters among Workers at Berber Cement Factory, Sudan' showed that allergy marker eosinophil was increased while other blood cell parameters were not affected which showed relation between exposure to cement dust and increase in blood eosinophils. Elevated differential cell counts predict the incidence of coronary heart disease (Hung \& Cherng, 2003). The basophil count was normal. Basophils have some role in immune surveillance, release histamine and other mediators and play a role in the initiation of allergic reactions and wound repair, occur in hypothyroidism, increase in blood lipids and tuberculosis. In the study by Lucijanic et al. (2017) on 'High absolute basophil count is a powerful independent predictor of inferior overall survival in patients with primary myelofibrosis' showed that high absolute basophil count reflected higher disease activity and poor prognosis. In this study elevated inflammatory markers may also indicate a higher risk for disability and premature death among the industrial workers. Some lifestyle changes, such as increasing exercise may help reduce inflammation and lower risk of adverse health effects. The average values of erythrocyte sedimentation rate were elevated $(5.98 \pm 31.63-73.51 \pm 28.47)$ in Ishiagu quarry industrial workers and control subjects that participated in health status investigation. In the study conducted by Bitik, et al. (2015) on Differential diagnosis of elevated erythrocyte sedimentation rate and C-reactive protein level: a rheumatology perspective', found out that in the general population, the most common etiology of nonspecific elevations in erythrocyte sedimentation rate level was as a result of new-onset Rheumatoid disease. Yousuf, Akhter, Al-Khairy, Al-Saadan, \& Bin-Salih (2010) conducted a study in 'Extremely elevated erythrocyte sedimentation rate aetiology at a tertiary care centre in Saudi Arabia' and found out that the patients with extreme erythrocyte sedimentation rate elevation have an underlying aetiology. Erythrocyte Sedimentation Rate is used as a medical screening test, a non-specific measure of inflammation and for a rapid diagnostic method for observation of changes in plasma protein. ANOVA $(\mathrm{p}<0.05)$ analysis revealed a significant difference in the mean concentrations of the measured health status parameters.

\subsubsection{Heavy Metal Level on the Hair of Workers}

The level of some heavy metals on the hair of workers in the selected industries varied as Lead was highest $(0.26 \pm 0.03 \mathrm{~mm} / \mathrm{l})$ among quarry workers. This could be from leaded gasoline used by these industries. It has been reported that leaded gasoline produced $90 \%$ of air emissions in the 1970s according to Reagan (1998), and was, therefore, a major source of contamination in the environment. Cadmium was $(0.12 \pm 0.01)$ which may likely have resulted from the incineration of electronic waste carried out there. The values of $\mathrm{Hg}$, As and $\mathrm{Cr}$, were $0.01 \pm 0.10,0.02 \pm 0.01$ and $0.11 \pm 0.06 \mathrm{mg} / \mathrm{l}$ respectively. It has been exhibited that heavy metals are found in fuels, fuel tanks, engines and other vehicle components, catalytic converters, tires and brake pads (Zehetner, Rosenfellner, Mentler, \& Gerzabek, 2009), which may be are suspected sources of the values recorded in this study.

\subsection{Air Quality in Ishiagu Industry, South-Eastern Nigeria}

The average level of $\mathrm{NO}_{2}, \mathrm{CO}_{2}, \mathrm{SO}_{2}, \mathrm{VOC}$, and TSPM ${ }_{10} \mu \mathrm{g} / \mathrm{m}^{3}$ were all above FEPA (1991) standard. The average values of CO were higher than the FEPA (1991) standard. Ibe, Opara, Njoku, \& Alinnor (2017) conducted a research on 'Ambient Air Quality Assessment of Orlu, Southeastern, Nigeria' and concluded that the mean level of $\mathrm{PM}_{10}, \mathrm{NO}_{2}$ and $\mathrm{CO}$ in all the air quality monitoring locations exceeded the US National Ambient Air Quality Standard. Ambient Air Quality Assessment of Orlu, Southeastern, Nigeria. While $\mathrm{SO}_{2}$ level was within Nigerian National Ambient Air Quality Standard limit. Nkwocha, \& Egejuru (2008) in an 18-month prospective study to assess the effects of industrial air pollutants on the respiratory health of children, provided a strong correlation between exposures to four criteria air pollutants, namely $\mathrm{CO}$, $\mathrm{NO}_{2}, \mathrm{SO}_{2}$, and $\mathrm{PM}_{10}$, and the incidence of bronchitis. ANOVA $(\mathrm{p}<0.05)$ analysis revealed a significant difference in the mean concentrations of the measured air pollutants. The findings of the present study suggest that anthropogenic activities in Ishiagu quarry industry and adjoining environment were responsible for the observed air quality level. The major limitation of air pollution and carbon management is the lack of data and concentration of major air pollutants in Nigeria. There is no monitoring station that contributes to data on concentration $\mathrm{CO}_{2}$, and another air pollutant VOCs. This inability of Nigerian ministries and agencies; Federal Ministry of Environment (FMEnv), Federal Environmental Protection Agency (FEPA), and Nigerian Meteorological agency (NIMET) to systematically and consistently measure the concentrations of air pollutants, hinder concerted efforts to achieving clean air in Nigeria.

\section{Conclusion}

The research of Ishiagu quarry industry in South-Eastern Nigeria revealed that the work environments were polluted with particulate matter that was made up of fine particles of heavy metals known to be hazardous to the health status of workers. Effective examination of the relationship between health and work-related factors among workers required the creation of new, longitudinal data sets containing detailed information on workers' employment health status, previous work histories of a representative sample and the specific demands of the job, as well as objective information on the job hazards. It has long been known that exposure to high level of certain chemicals, such as those in Ishiagu quarry industry, can cause cancer and other health problems. 


\section{References}

i. AbdElhamid, H., Mohammed, M. N., Alrazig, S. A., TajAlser, T., Suliman, E., Allah, K. A., Muzamil, N., Ahmed, E. S., Albakry, M. M. \& Altaib, Z. (2017). Assessment of Allergy Marker Leucocyte (Eosinophil) Count and other Blood Cells Parameters among Workers at Berber Cement Factory, Berber Governorate, River Nile State, Sudan. Global Journal of Medical Research: Microbiology and Pathology 17 (1): 1.0 Type: Double Blind Peer Reviewed International Research Journal Publisher: Global Journals Incorporated. (USA) Online ISSN:2249-4618 \& Print ISSN: 0975-5888.

ii. Achyut, A., Shrestha, T. K., Shree Sen, D., Uprteti, B., \& Gautam, N. (2009). Conservation Regime and Local

iii. Population Ecology of Sarus Crane (Grus Antigone) in the West Central Region of Nepal, Journal of

iv. Wetlands Ecology, (2009) 3: 1-11.

v. Adams, C. (1987). Becton Dickinson and Company Manual. N=umber 4440. Revision F 7/ 87)

vi. Aroh, K. N., Ubong, I. U., Eze, C. L., Harry, I. M., Umo-Otong, J. C., Gobo A. E. (2010). "Oil spill incidents and pipeline vandalization in Nigeria: Impact on public health and negation to the attainment of development goal: the Ishiagu example". Disaster Prevention and Management. 19 (1): 70-87.

vii. Bitik, B., Mercan, R., Tufan, A., Tezcan, E., Küçük, H., İlhan, M., Öztürk, M. A., Haznedaroğlu, Göker, B. (2015). Differential diagnosis of elevated erythrocyte sedimentation rate and protein level: a rheumatology perspective. Europian Journal of Rheumatology. DOI: 10.5152/ eurjrheum.2015.0113

viii. CROWCON (2014). $\mathrm{Co}_{2}$-gas-hazards-brewing-industry. Retrieved from HTTP:// www.crowcon.com/ article/ 6/ $\mathrm{co}_{2}$ gas-hazards-brewing-industry.

ix. David, M. (2007). Cardiothoracic Critical Care, Pulmonary consolidation - an overview. ScienceDirect. Retrieved from:https:/ / www.sciencedirect.com/ topics/ medicine-and-dentistry/ pulmonary-

x. Federal Environmental Protection Agency (1991). Guidelines and Standards for Environmental Pollution Control in Nigeria. Lagos: Federal Ministry of Environment.

xi. Federal Ministry of Environment (FMENV) (1991). National Environmental Protection (Effluent Limitation) Regulations, S.I.8 published by the Federal Government Press, Lagos, Nigeria and FGPL. 211/ 991/ 12000.

xii. Gant, S. (2017). Overview of Carbon Capture and Storage (CCS) Projects at HSE's Buxton Laboratory. UK: HSE, RR1121 http:/ / www.hse.gov.uk/ research/ rrpdf/ rr1121.

xiii. Garcia, M. W. (May 10-12, 2017). Novel application of the bow tie technique for the analysis of the NFPA 59A standard.

xiv. Hall, S. (2017). An assessment of occupational exposure to metal powders used for additive manufacturing (AM). Occupational Hazards 2017 (p. 24-27). UK: Harrogate

xv. Hung, M. J. \& Cherng, W. J. (2003) Comparison of white blood cell counts in acute myocardial infarction patients with significant versus insignificant coronary artery disease American Journal of Cardiology, 91 (2003), pp. 13391342.

xvi. Ibe, F. C., Opara, A. I., Njoku, P. C. \& Alinnor, J. I. (2017). Ambient Air Quality Assessment of Orlu, Southeastern, Nigeria. Journal of Applied Sciences, 17: 441-457.DOI: 10.3923/jas.2017.441.457 URL: https:/ / scialert.net/ abstract/ ?doi=jas.2017.441.457

xvii. James, B., Haenel. R.T., Jeffrey, L. \& Johnson, M. D. (2011). Acute Respiratory

xviii. Distress Syndrome; Anesthesia Secrets (Fourth Edition), Science Direct.

xix. https:/ / www.sciencedirect.com/ topics/ medicine-and-dentistry/ pulmonary-

xx. Landrigan, P. J. (2018). The Lancet Commission on pollution and health. The Lancet Commissions, 391(10119): 462-512.

xxi. Lucijanic, M., Livun, A., Stoos-Veic, T., Pejsa, V., Jaksic, O., Cicic, D., Lucijanic, J., Romic, Z., Orehovec, B., Aralica, G., Miletic, M. \& Kusec, R. (2017). High absolute basophil count is a powerful independent predictor of inferior overall survival in patients with primary myelofibrosis, Hematology. DOI:10.1080/ 10245332.2017.1376843

xxii. Liu, W. Z. (2017). Performance, acute health symptoms and physiological responses during exposure to high air temperature and carbon dioxide concentration. Building and Environment, 114: 96-105.

xxiii. Luo, J. C., Hsieh, L. L., Chang, M. J., Hsu, K. H. (2002). Decreased white blood cell counts in semiconductor manufacturing workers in Taiwan Occupational and Environmental Journals BMJ (59), 1.

xxiv. Nkwocha, E. E. \& Egejuru, R.O. (2008) Effects of Industrial Air Pollution on the Respiratory Health of Children. International Journal Environmental Science Technology, 5: 509-516. [CrossRef]

xxv. Obinwanne, C. C. (2018) Occupational and Ecotoxicological Hazards associated with selected industries in South-

xxvi. Eastern Nigeria. Owerri: Department of Biotechnology of the Federal University of Technology.

xxvii. Ostlin, P. (2000). Gender inequalities in occupational health. Boston: Harvard University; p. 5.

xxviii. (Working paper; gender and health equity series).

xxix. Richard, L. \& Kradin, M.D. (2017) Understanding Pulmonary Pathology Retrieved from: https:/ / www.sciencedirect.com/ topics/ medicine-and-dentistry/ pulmonary-) Health Perspective, $217-229$.

xxx. Tankeshwar, P. (December 6, 2013). The principle, Procedure and reporting Bacteriology, laboratory diagnosis of Bacterial Disease, Staining techniques in Microbiology, 24. Retrieved from: https://microbeonline.com > Bacteriology

xxxi. WHO (2007). Guidelines for drinking-water quality (Fourth edition), Cadmium, chapter 12.1, pp. 
xxxii. WHO, UNICEF, UNU (2001). Iron deficiency anaemia: assessment, prevention and control, a guide for Programme managers, Geneva, Horld http:/ / www.who.int/ nutrition/ publications/ micronutrients/ anaemia iron_deficiency/WHO_NHD 01.3/ en/index.html

xxxiii. Yousuf, M., Akhter, J., Al-K̄hairy, K., Al-Saadan, M. A. \& Bin-Salih, S. (2010). Extremely elevated erythrocyte sedimentation rate Etiology at a tertiary care centre in Saudi Arabia. Saudi Medical Journal. 31 (11): 1227-1231.

xxxiv. Zehetner, F., Rosenfellner, U., Mentler, A. \& Gerzabek, M.H. (2009). Distribution of road salt residues, heavy metals and polycyclic aromatic hydrocarbons across a highway-forest interface. Water Air Soil Pollution. 198:125-132. DOI: $10.1007 /$ s11270-008-9831-8.

AFB: $\quad$ Acid Fast Bacilli

\section{Abbreviations}

ANOVA: Analysis Of Variance

BASO: Basophils

C: $\quad$ Consolidation Of The Lung

C-XRAY:Chest X-Ray

EDTA: Ethylenediaminetetraacetic Acid

EOSIN: Eosinophils

F: $\quad$ Female

FEPA: Federal Environmental Protection Agency

GP: $\quad$ Group

HB: Haemoglobin

HG: $\quad$ Mercury

LYMPH: Lymphocytes

M: $\quad$ Male

MONO: Monocytes

$\mathrm{N}$ : Normal

NEUT: Neutrophils

NIMET: Nigerian Meteorological Agency

NMVOCS: Non-Methane Volatile Organic Compounds

$\mathrm{NO}_{2}$ : Nitrogen Dioxide

NS: $\quad$ None Specified

PM10: Particulate Matter

$\mathrm{SO}_{2}$ : $\quad$ Sulfur Dioxide

TSPM: Total Suspended Particulate Matter

UNESCO: United Nations Educational, Scientific and Cultural Organization

UNICEF:United Nations International Children Emergency Fund

UNU: United Nations University

VOC: Volatile Organic Compounds

WHO: World Health Organization

YRS: Years 